\title{
CORRECTION
}

\section{Correction to: BRG1 regulation by miR-155 in human leukemia and lymphoma cell lines}

\author{
M. Cuadros ${ }^{1,2} \cdot$ V. Sánchez-Martín ${ }^{1,2}$ (1) A. Herrera-Merchan ${ }^{2,3} \cdot$ C. Baliñas $^{2} \cdot$ J. Martín-Padrón $^{1,2} \cdot$ L. Boyero ${ }^{1,2}$. \\ P. Peinado ${ }^{2,3}$. P. P. Medina ${ }^{2,3}$
}

Published online: 26 July 2019

(C) Federación de Sociedades Españolas de Oncología (FESEO) 2019

\section{Correction to: Clin Transl Oncol (2017) 19:1010-1017 https://doi.org/10.1007/s12094-017-1633-2}

Following the publication of the original article the author listed as Antonio Herrera contacted the Publisher to state that his correct and full name is Antonio Herrera-Merchan. Antonio Herrera-Merchan has agreed to the publication of this erratum.

Pedro Medina, Victoria Sánchez-Martín, Carlos Baliñas, Laura Boyero, Paola Peinado did not agree to the publication of this erratum.

Marta Cuadros and Joel Martin-Pedron did not respond to the correspondence from the journal regarding this erratum.

Publisher's Note Springer Nature remains neutral with regard to jurisdictional claims in published maps and institutional affiliations.

The original article can be found online at https://doi.org/10.1007/ s12094-017-1633-2.

1 Department of Biochemistry and Molecular Biology III and Immunology, University of Granada, Granada, Spain

2 GENYO, Centre for Genomics and Oncological Research, Granada, Spain

3 Department of Biochemistry and Molecular Biology I, University of Granada, Granada, Spain 